\title{
The Effect of Human-Immunodeficiency Virus Status on Outcomes in Penetrating Abdominal Trauma: An Interim Analysis
}

\author{
McPherson, Deidre ; Neuhaus, Valentin ; Dhar, Rohin ; Edu, Sorin ; Nicol, Andrew J ; Navsaria, \\ Pradeep H
}

\begin{abstract}
BACKGROUND The purpose of this study was to determine whether the outcomes of hemodynamically stable patients undergoing exploratory laparotomy for penetrating abdominal trauma differed as a result of their HIV status. METHODS This was an observational, prospective study from February 2016 to May 2017. All hemodynamically stable patients with penetrating abdominal trauma requiring a laparotomy were included. The mechanism of injury, the HIV status, age, the penetrating abdominal trauma index (PATI), and the revised trauma score (RTS) were entered into a binary logistic regression model. Outcome parameters were in-hospital death, morbidity, admission to intensive care unit (ICU), relaparotomy within 30 days, and length of stay longer than 30 days. RESULTS A total of 209 patients, $94 \%$ male, with a mean age of $29 \pm 10$ years were analysed. Twenty-eight patients (13\%) were HIV positive. The two groups were comparable. Ten (4.8\%) laparotomies were negative. There were two $(0.96 \%)$ deaths, both in the HIV negative group. The complication rate was $34 \%(\mathrm{n}=72)$. Twenty-nine patients $(14 \%)$ were admitted to the ICU. A higher PATI, older age, and a lower RTS were significant risk factors for ICU admission. After 30 days, 12 patients (5.7\%) were still in hospital. Twenty-four patients (11\%) underwent a second laparotomy. The PATI score was the single independent predictor for complications, relaparotomy, and hospital stay longer than 30 days. CONCLUSIONS Preliminary results reveal that HIV status does not influence outcomes in patients with penetrating abdominal trauma.
\end{abstract}

DOI: https://doi.org/10.1007/s00268-018-4502-4

Posted at the Zurich Open Repository and Archive, University of Zurich

ZORA URL: https://doi.org/10.5167/uzh-158808

Journal Article

Accepted Version

Originally published at:

McPherson, Deidre; Neuhaus, Valentin; Dhar, Rohin; Edu, Sorin; Nicol, Andrew J; Navsaria, Pradeep H (2018). The Effect of Human-Immunodeficiency Virus Status on Outcomes in Penetrating Abdominal Trauma: An Interim Analysis. World Journal of Surgery, 42(8):2412-2420.

DOI: https://doi.org/10.1007/s00268-018-4502-4 


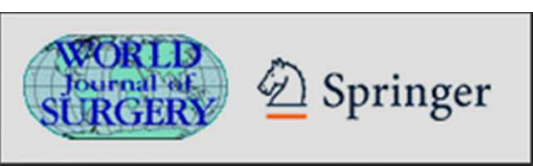

\section{The effect of human-immunodeficiency virus status on outcomes in penetrating abdominal trauma - an interim analysis}

\begin{tabular}{|r|l|}
\hline Journal: & World Journal of Surgery \\
\hline Manuscript ID & WJS-17-10-1609.R1 \\
\hline Manuscript Type: & Original Scientific Report \\
\hline Date Submitted by the Author: & $25-$-Dec-2017 \\
\hline Complete List of Authors: & $\begin{array}{l}\text { McPherson, Deidre; Trauma Center: Groote Schuur Hospital, Surgery } \\
\text { Neuhaus, Valentin; Trauma Center: Groote Schuur Hospital, Surgery; } \\
\text { University Hospital Zurich, Division of Trauma Surgery } \\
\text { Dhar, Rohin; Trauma Center: Groote Schuur Hospital, Surgery } \\
\text { Edu, Sorin; Trauma Center: Groote Schuur Hospital, Surgery } \\
\text { Nicol, Andrew; Trauma Center: Groote Schuur Hospital, Surgery } \\
\text { Navsaria, Pradeep; University of Cape Town and Groote Schuur Hospital, } \\
\text { Surgery: Trauma }\end{array}$ \\
\hline Keywords: & Trauma, Outcomes, Infection \\
\hline \multicolumn{2}{|c}{} \\
\hline \multicolumn{2}{|c}{} \\
\hline
\end{tabular}




\section{Affiliation}

1. Trauma Center, Department of Surgery, Groote Schuur Hospital, University of Cape Town, Observatory, 7925 Cape Town, South Africa

\section{Correspondence address}

Prof. Pradeep H. Navsaria

MBChB, FCS(SA), MMed(Surgery), Trauma Surgery(HPCSA), FACS

Trauma Centre

Groote Schuur Hospital and University of Cape Town

Observatory

7925 Cape Town

South Africa

Tel.: +27 (21) 4044556

E-mail: pradeep.navsaria@uct.ac.za

\section{Keywords}


HIV; laparotomy; penetrating abdominal trauma

\section{Sources of Funding}

This research did not receive any specific grant from funding agencies in the public, commercial, or not-for-profit sectors.

\section{Conflicts of interest}

The authors have no conflict of interest with this manuscript.

\section{Final word count}

$2 \underline{594} 396$ 


\section{Abstract}

Background: The purpose of this study was to determine whether the outcomes of hemodynamically stable patients undergoing exploratory laparotomy for penetrating abdominal trauma differed as a result of their HIV-status.

Methods: This was an observational, prospective study from February 2016 to May 2017. All hemodynamically stable patients with penetrating abdominal trauma requiring a laparotomy were included. The mechanism of injury, the HIV-status, age, the penetrating abdominal trauma index (PATI), and the revised trauma score (RTS) were entered into a binary logistic regression model. Outcome parameters were in-hospital death, morbidity, admission to intensive care unit (ICU), relaparotomy within 30 days, and length of stay longer than 30 days.

Results: A total of 209 patients, $94 \%$ male, with a mean age of $29 \pm 10$ years were analysed. Twenty-eight patients (13\%) were HIV positive. The two groups were comparable. Ten $(4.8 \%)$ laparotomies were negative. There were two $(0.96 \%)$ deaths, both in the HIV negative group. The complication rate was $34 \%(n=72)$. Twenty-nine patients $(14 \%)$ were admitted to the ICU. A higher PATI, older age, and a lower RTS were significant risk factors for ICU admission. After 30 days, 12 patients (5.7\%) were still in hospital. Twenty-four patients $(11 \%)$ underwent a second laparotomy. The PATI score was the single independent predictor for complications, relaparotomy and hospital-stay longer than 30 days.

Conclusions: Preliminary results reveal that HIV-status does not influence outcomes in patients with penetrating abdominal trauma. 
Introduction

HIV infection and trauma are significant contributors to the burden of disease in South Africa. More than 70 million people worldwide have been infected with the Human Immunodeficiency Virus (HIV) since 1981; half of them have since died.[1] Seven million people with HIV were living in South Africa in 2016.[2] In 2010, HIVIAIDS accounted for the leading cause of death in Cape Town (13\%), followed by interpersonal violence $(9.7 \%$ mainly penetrating injuries) and tuberculosis (7.7\%).[3] Although HIV and the acquired immunodeficiency syndrome (AIDS) can potentially affect outcomes, there have been few studies comparing trauma outcomes in HIV positive versus HIV negative patients. The association between HIV and the outcome of surgery remains unanswered with many studies yielding conflicting results. HIV treatment has also made paramount improvements in the past decades and as a result, HIV positive patients can now live a normal life. Despite this, in some previous studies there seems to be a tendency towards a higher morbidity and mortality in HIV positive patients undergoing trauma surgery.[4-7] While some of these studies did compare HIV positive to HIV negative patients, they considered all mechanisms of trauma and did not differentiate between blunt and penetrating injuries. No studies have been conducted on penetrating abdominal trauma and the influence of HIV on outcomes. The senior authors of this study experienced anecdotally that the HIV status of trauma patients did not influence the outcome, however it seemed that patients with AIDS had poorer results.

The primary purpose of this study was to determine whether the HIV status of hemodynamically stable patients undergoing exploratory laparotomy for penetrating abdominal trauma had any influence on outcomes. The secondary objectives of the study were to determine whether CD4 count in the HIV positive patients plays a role in the outcome of these patients. The endpoint of this study is to provide general and trauma surgeons performing trauma laparotomy with some insight on the expected outcomes of procedures for a HIV positive patient with major penetrating abdominal trauma. 
2

3

4

5

6

7

8

9

10

11

12

13

14

15

16

17

18

19

20

21

22

23

24

25

26

27

28

29

30

31

32

33

34

35

36

37

38

39

40

41

42

43

44

45

46

47

48

49

50

51

52

53

54

55

56

57

58

59

60 


\section{Material and Methods}

In a prospective, observational study from February 2016 to May 2017_(16 months), all patients admitted with a penetrating abdominal injury requiring a laparotomy at a Level I trauma centre in Cape Town, South Africa, were considered for inclusion in this study. This study was approved by the human research ethics committee (HREC: 819/2015) of the University of Cape Town and Groote Schuur hospital.

The inclusion criteria was hemodynamic stability, penetrating abdominal trauma with an inherent need for laparotomy as result of a peritonitic abdomen, a signed informed consent, and a HIV test. Patients who had more than one area of penetrating trauma, as well as patients with blunt trauma elsewhere were included in the study, as long as the other inclusion criteria were met. Patients undergoing a damage control procedure at the index operation were excluded. However, the attending surgeon may have opted for a damage control procedure in the patient who was initially hemodynamically stable, and these patients were also included in the study. All patients were treated as per our institutional protocol and received the same presumptive preoperative antibiotic coverage, postoperative analgesia and antibiotic regimen.

\section{Safety measures including gloves, googles, and protective wear are routinely used. A standard post-exposure prophylaxis procedure is in place in our trauma unit for ALL health care providers in our hospital in case of a needle-stick injury or exposure to bodily fluids. Blood tests of the exposed and source person is obtained. A highly active antiretroviral 3- drug regimen is commenced within 1-2 hours of exposure. Further treatment is based on source patient status and the healthcare worker is further followed up by occupational health department for counselling and further management.}


Once it was clinically determined that the patient required a laparotomy, informed consent for surgery was taken. As it was a concern that these individuals would be vulnerable at the time of going for surgery, participants for the study were recruited post-operatively. Pre- and post-test counselling for HIV testing was done by trained medical practitioners. A standardized counselling form was used. Those individuals with known HIV positive status before inclusion in the study were retested. The HIV test was done after the patient had surgery performed. This was to ensure that patients completely understood the study, would not feel vulnerable and would be able to give proper informed consent. The CD4 count was also performed post-operatively after the HIV test was done, and was confirmed positive. The HIV testing was done with ELISA testing and in cases where the test was confirmed positive, a confirmatory test was done as is in line with provincial guidelines. All newly diagnosed HIV positive patients are eligible for ART (local provincial guidelines of the Western Cape published at http://www.mic.uct.ac.za). Newly diagnosed HIV positive patients are not routinely commenced on antiretroviral therapy during the index hospitalization. It has been found that the compliance rate is significantly better when the ART is started at their local clinic where they can be regularly followed up. Therefore, patients were referred to a local clinic for further HIV counselling and treatment once they were discharged. A 3-drug regimen is commenced and the monitoring process is clearly described at the above website. Newly diagnosed HIV positive patients are not routinely commenced on antiretroviral therapy as per provincial guidelines. Once patients were discharged they were referred to a local clinic for further HIV counselling and treatment.

Basic demographics, mechanisms of injury, laparotomy findings, estimated intra-operative blood loss, length of hospital stay, admission to ICU, morbidity and mortality were recorded. The Charlson Comorbidity Index (CCl) was used to calculate the severity of comorbidities. [8] Injury severity was categorized calculating the physiological scores (Revised Trauma Score (RTS) and Kampala score[9, 10]), and the anatomical scores (American Association for the Surgery of Trauma (AAST), Abbreviated Injury Scale (AIS)[11], Injury Severity Score (ISS), 
and Penetrating Abdominal Trauma Index (PATI)[12]). Complications were grouped according to the Clavien-Dindo classification.[13] Hemodynamically stable patients had a systolic BP greater than $90 \mathrm{mmHg}$. Responders were patients with an initial BP lower than $90 \mathrm{mmHg}$, however stabilized after 1-2-litres of fluid. A peritonitic abdomen was based on the physician's clinical judgement.

The primary outcome was morbidity defined as presence of one or more complications. Secondary outcomes were in-hospital death, admission to intensive care unit (ICU), relaparotomy within 30 days, and length of stay. The patients were stratified into two groups, HIV negative and HIV positive, for the analysis. The association between the CD4 counts, CDC stage, and morbidity in the HIV positive group were further analysed.

A sample size of 205 patients was needed to achieve a power of $80 \%$ and type I error rate of $5 \%$, if the complication rate of the HIV negative group is $7 \%[4,7]$, the sampling ratio of HIV negative : HIV positive is 9 , and we assume a clinically relevant difference of $7 \%$ compared to the HIV negative group, that is $14 \%$ [4-7]. Continuous data was presented in mean and standard deviation numbers, and categorical data in absolute and relative numbers. Chisquare, F-Mann-Whitney $U$, and Fisher-test, where applicable, were used to do bivariate analysis. HIV status and the bare minimum (patient age, PATI score for anatomic severity, RTS score for physiologic severity, and mechanism of injury) were entered in multivariate binary logistic regression analysis to evaluate HIV as an independent predictor for a negative outcome (morbidity, in-hospital death, admission to ICU, relaparotomy within 30 days, and length of stay longer than 30 days). Since female gender had a low prevalence, this co-factor could not be entered into regression analysis. $\mathrm{P}<0.05$ was considered statistically significant. The Statistical Package for Social Sciences (SPSS, Version 23, IBM Corp., Armonk, NY, USA) was used for statistical analysis. 


\title{
Results
}

The cohort consisted of 209 patients, 196 (94\%) men and 13 women, with a mean age of 29 (SD +/-10) years. Twenty-eight patients (13\%) were HIV positive. We diagnosed 21 new positive HIV cases. Seven patients were aware of their HIV status prior to this admission. None of them were on ART. The HIV positive and negative groups were comparable except for race, Charlson Comorbidity Index score, and admission delay.(Table 1) All patients underwent an exploratory laparotomy. Of these, 10 (4.8\%) were negative or non-therapeutic. Six patients $(2.9 \%)$ had missed intraabdominal injuries, four with small intestine perforations, one diaphragm laceration, and one bile duct injury.

\begin{abstract}
Morbidity
Seventy-two patients (34\%) had one or more complications (Table 2). The three most common complications were: surgical site infections (12\%), post-operative ileus (8.6\%), and sepsis $(6.2 \%$; including intra-abdominal collections, septic shock, urinary tract infections, pneumonia, bullet tract sepsis), which were not significantly associated with the HIV status. There was no noticeable impact of patient age on outcome within the HIV positive $(p=0.915)$ or negative only group $(p=0.829)$. In bivariate analysis, the PATI score $(p=0.001)$, liver packing $(p=0.004)$, splenectomy $(p=0.009)$, colonic resection with primary anastomosis $(p=0.036)$, distal pancreatectomy $(p=0.007)$, wide drainage of the pancreas $(p=0.019)$, nephrectomy $(p=0.049)$, longer duration of the first operation $(p<0.001)$, use of vasopressors intraoperative $(p=0.045)$, need for blood products $(p=0.001)$, and higher estimated blood loss $(p=0.001)$ were associated with morbidity. In multivariate analysis, the PATI score was the only single independent predictor $(p=0.001$, OR $1.057,95 \% \mathrm{Cl} 1.023-1.091)$ for morbidity. HIV was not an independent predictor for morbidity.
\end{abstract}

Mortality 
Two patients $(0.96 \%)$, both HIV negative, died during the hospitalization, one from hypovolemic shock secondary to rebleeding from a liver injury, and the other one from septic shock from overwhelming sepsis secondary to intraabdominal contamination following a destructive colonic injury. There was no mortality in the HIV positive group.

\title{
Admission to ICU
}

Twenty-nine patients (14\%) were admitted to the ICU. The mean duration of stay was 5.0 $(\mathrm{SD}+/-7.3)$ days, and $3.6(\mathrm{SD}+/-6.5)$ days of ventilation. Age $(p=0.007)$, RTS $(p=0.014)$, the Kampala score $(p=0.006)$, the PATI score $(p=0.023)$, thoracoabdominal injuries $(p=0.012)$, insertion of an intercostal drain $(p=0.002)$, liver packing $(p=0.029)$, duodenal repair $(p=0.003)$, wide drainage of the pancreas $(p=0.004)$, longer duration of the first operation $(p=0.024)$, use of vasopressors intraoperatively $(p<0.001)$, need for blood products $(p<0.001)$, and higher estimated blood loss $(p=0.004)$ were associated with admission to ICU. Older age ( $\mathrm{p}=0.07$, OR 1.056, 95CI\% 1.015-1.098), a higher PATI score $(\mathrm{p}=0.018, \mathrm{OR}$ $1.043,95 \% \mathrm{Cl} 1.007-1.080)$, and a lower RTS ( $\mathrm{p}=0.002$, OR $0.089,95 \% \mathrm{Cl} 0.020-0.399)$, but not HIV status, were independent predictors for admission to an ICU.

\section{Hospitalization more than 30 days}

After 30 days, 12 patients (5.7\%) were still in hospital. An acute spinal cord injured patient $(p=0.024)$, drainage of the pancreas $(p=0.040)$, the PATI score $(p=0.043)$, duration of the first operation $(p<0.001)$ and the estimated blood loss $(p=0.030)$ were associated with more than 30 days of hospitalization. PATI score again, was the single independent predictor in multivariate analysis $(p=0.001, \mathrm{OR} 1.082,95 \% \mathrm{Cl} 1.031-1.135)$.

\author{
Relaparotomy within 30 days \\ Twenty-four patients (11\%) underwent a relaparotomy. The reasons were planned (damage \\ control, $n=7)$, new or ongoing bleeding $(n=3)$, intestinal obstruction $(n=2)$, omental \\ evisceration $(n=1)$, multiple intraabdominal abscesses $(n=1)$, peritonitic / septic $(n=3)$, or
}


other reasons $(n=7)$. The PATI score $(p=0.046)$, liver packing $(p=0.006)$, stomach repair $(p=0.041)$, longer duration of the first operation $(p=0.047)$, use of vasopressors intraoperative $(p=0.005)$, need for blood products $(p=0.001)$, and higher estimated blood loss $(p=0.023)$ were associated with relaparotomy. The PATI score $(p=0.003$, OR $1.052,95 \% \mathrm{Cl}$ 1.017-1.088) was again the only significant predictor of relaparotomy.

Other findings

Twenty-two patients had CD4-counts: $31.8 \%$ were stage 1 (CD4 count > 500 cells/ $\mu$ l), $36.4 \%$ were stage 2 (CD4 count $200-499$ cells $/ \mu \mathrm{l}$ ), and $31.8 \%$ were stage 3 (CD4 count

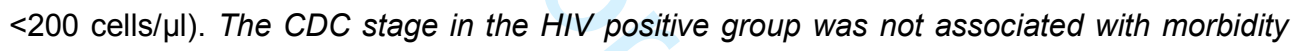
$(p=0.380)$. The average CD4 count in the HIV positive group was $401+/-254$. It too, was also not associated with morbidity $(p=0.234)$. 


\section{Discussion}

Globally, 36.7 million people were living with HIV at the end of 2015.[14] South Africa has the highest prevalence in Africa. The Western Cape Province of South Africa, where the study was conducted, has approximately 6.3 million people[2] with a HIV prevalence of $16.9 \%$ in 2011.[15] Trauma-related mortality, particularly due to interpersonal violence and road traffic injuries, remains extremely high and specifically amongst young adult males: 170 per 100000 in age group $20-24$ years.[16] It is therefore, not uncommon for young adult patients, who are HIV positive, who have sustained some sort of trauma, to be managed in our-busy level I urban trauma centre.

The association between HIV and the outcomes of surgery has been previously studied. In 2009, Madiba et al. compared surgery in HIV negative, HIV positive, and AIDS patients and evaluated the outcomes. The results indicated that the outcomes of surgery for patients, who are HIV negative, HIV positive and those with AIDS, are variable in terms of morbidity, mortality, and duration of hospital stay. HIV positive patients without AIDS-defining criteria have a surgical course similar to that of HIV negative patients. HIV infection should therefore not be considered as a significant independent factor for major surgical complications. The study concluded that appropriate surgery should be offered as per normal surgical patients without the concern of an unfavourable outcome.[17] Since 2008, a further dozen reports have compared HIV positive and negative surgical patients. Of all these, only six investigated the trauma population which included predominantly blunt mechanism of trauma (more than $80 \%$ ). Table 3 is an extended summary of the conclusions of the current available literature on HIV status and surgical outcomes.[3]

In this study, the incidence of HIV is similar to that in the Western Cape Province. In hemodynamic stable patients requiring laparotomy for penetrating abdominal trauma, the 
HIV status was not an independent predictor for morbidity, ICU admission, length of hospital stay, and relaparotomy.

A CD4 count greater than 200 cells/ $\mu$ l has been shown to be a good marker of immune function in patients who are HIV positive. Most of our patients were CDC stage 2 (CD4 count between 200 and 500 cells/fll) with an average of 400 . With certain limitations, The the CD4 count did not influence outcome of our patients and since none of our patients were on ART during the time of the study, as such did not make a difference in outcome. The CDC staging does not have any impact on the progress and outcome of the patient undergoing an exploratory laparotomy in this study. This is in contrast to previous studies which suggested that the CDC staging has a direct impact on the outcome of the HIV positive patient. In multivariate analysis, the PATI score was the only single independent predictor for morbidity, ICU admission, length of stay and relaparotomy. There were only two deaths, both HIV negative patients, suggesting that HIV was probably not an independent predictor of mortality.

Despite the prospective design, the study has several limitations. The viral load was not available due to cost constraints. This could have helped to further stratify the HIV positive patients and allow us to investigate the influence of viral load, if any, on outcomes. Similar, the CD4 counts were measured post-operative and not available in $20 \%$, which makes the $\underline{\text { CDC staging questionable. }}$

There were 41 patients who refused HIV testing and as such could not be included in our study. Despite adequate counselling about HIV testing, and numerous public health programs underway in the country, including the VCT program (voluntary testing and counselling), there appears to be still a reluctance amongst young adult males to be tested. This must be improved. However, the opt-out approach should be adopted because the overall test rates and disease identification rates were better than with other systems. [18] 
Although the mortality rate was very low, we are not able to make any definitive conclusion about HIV status in the current study. To achieve statistical significance in difference in mortality between the two groups, a population of 702 patients is required. The study is still ongoing and recruiting patients for this specific purpose.

In summary, trauma patients with HIV are frequently seen in busy trauma centers in South Africa. We found that the incidence of HIV in our cohort was $13 \%$, which is similar to the reported incidence of HIV in the Western Cape. There were no significant baseline differences between the HIV positive and HIV negative groups. The patient's HIV status as well as the CD4-count-did not influence their outcomes in penetrating abdominal trauma and we recommend that these patients be treated as HIV negative patients. The PATI score was found to be a significant predictor of morbidity and was validated in our cohort of patients, as higher PATI scores were associated with poorer outcomes. 
Table 1: Overview of Results

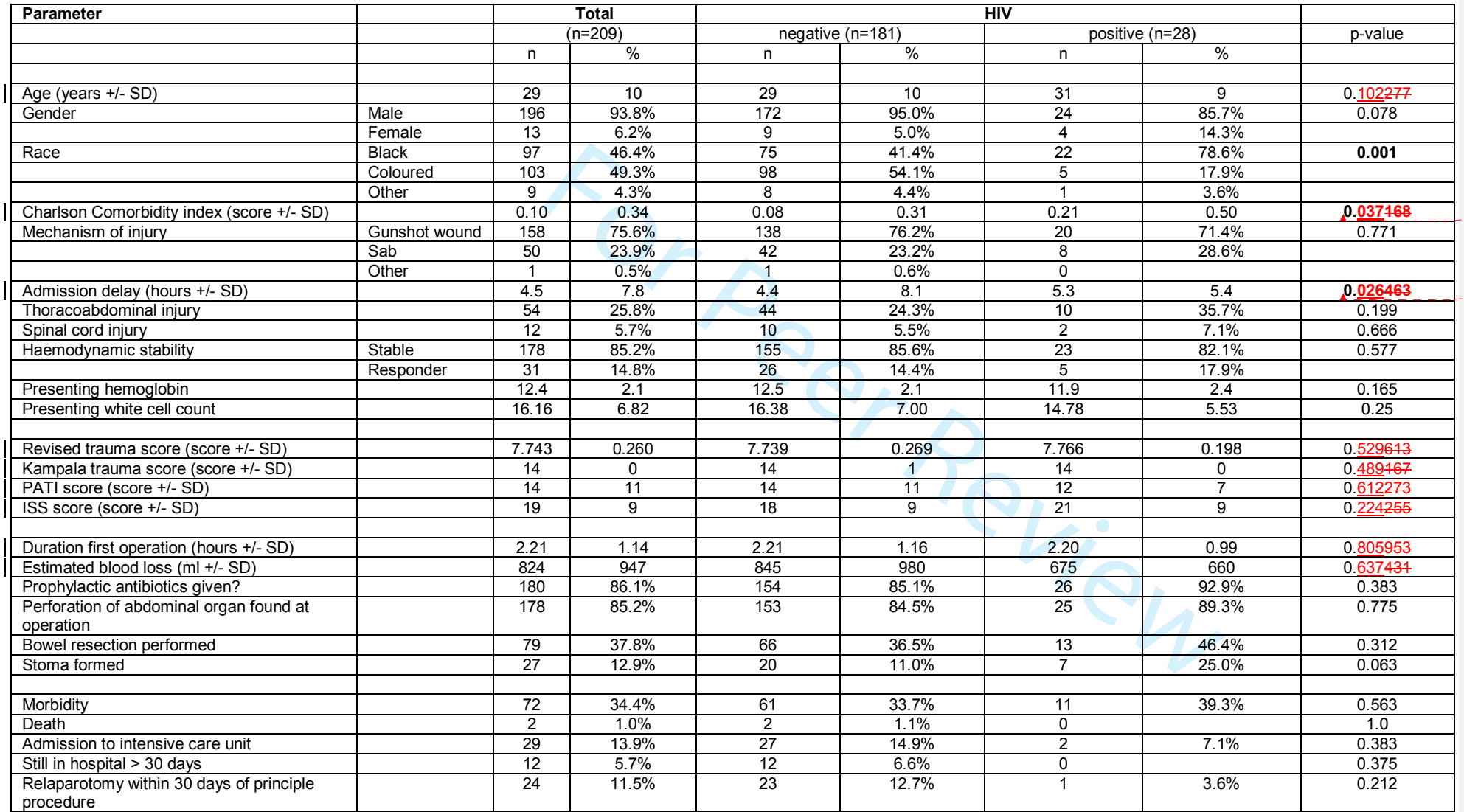

Formatted: Font: Bold

Formatted: Font: Bold 
Table 2: Complications according to Clavien-Dindo Classification

\begin{tabular}{|c|c|c|c|c|c|c|c|c|}
\hline \multirow[t]{3}{*}{ Complications } & & \multicolumn{2}{|c|}{ Total } & \multicolumn{4}{|c|}{ HIV } & \multirow[t]{3}{*}{ p-value } \\
\hline & & & & \multicolumn{2}{|c|}{ negative } & \multicolumn{2}{|c|}{ positive } & \\
\hline & & $\mathrm{n}$ & $\%$ & $\mathrm{n}$ & $\%$ & $\mathrm{n}$ & $\%$ & \\
\hline None & No & 137 & $65.6 \%$ & 120 & $66.3 \%$ & 17 & $60.7 \%$ & 0.563 \\
\hline Grade & I & 12 & $5.7 \%$ & 11 & $6.1 \%$ & 1 & $3.6 \%$ & \\
\hline & II & 23 & $11.0 \%$ & 17 & $9.4 \%$ & 6 & $21.4 \%$ & 0.105 \\
\hline & Illa & 11 & $5.3 \%$ & 9 & $5.0 \%$ & 2 & $7.1 \%$ & \\
\hline & IIIb & 13 & $6.2 \%$ & 12 & $6.6 \%$ & 1 & $3.6 \%$ & \\
\hline & IVa & 3 & $1.4 \%$ & 3 & $1.7 \%$ & 0 & $0.0 \%$ & \\
\hline & $\mathrm{IVb}$ & 8 & $3.8 \%$ & 7 & $3.9 \%$ & 1 & $3.6 \%$ & \\
\hline & $\mathrm{V}$ & 2 & $1.0 \%$ & 2 & $1.1 \%$ & 0 & $0.0 \%$ & \\
\hline
\end{tabular}


Table 3: Overview of studies comparing surgical HIV negative and HIV positive patients

\begin{tabular}{|c|c|c|c|c|c|}
\hline Authors & Country & Year & $\mathrm{N}$ & Discipline & Conclusions \\
\hline Von trauma & & & & & \\
\hline 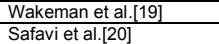 & $\frac{U K}{U S A}$ & $\frac{1990}{1991}$ & $\frac{112}{62}$ & 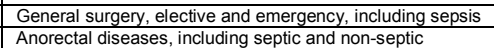 & $\begin{array}{l}\text { HIV positive patients have a slower wound healing } \\
\text { AlDS patients have a poor realing }\end{array}$ \\
\hline $\begin{array}{l}\text { Ayers et al.[21] } \\
\text { Binderow et al.[22] }\end{array}$ & $\begin{array}{ll}\text { USA } \\
\text { USA }\end{array}$ & $\frac{1993}{1993}$ & $\frac{34}{25}$ & \begin{tabular}{|l|} 
All surgicalal isciplines \\
General surgical patients \\
\end{tabular} & 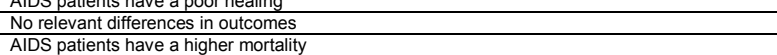 \\
\hline \begin{tabular}{l|} 
Devito and Robiinson[23] \\
Consten et al.124]
\end{tabular} & $\frac{5 \mathrm{~A}}{\text { The Netherlands }}$ & $\frac{1995}{1995}$ & 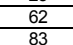 & \begin{tabular}{|l|} 
Gynnecological surgery \\
Anorectad liseases including septic and non-septic \\
\end{tabular} & 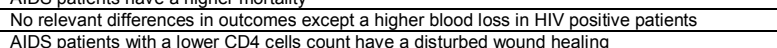 \\
\hline $\begin{array}{l}\text { Consten et al.124] } \\
\text { Yiiet all[2a] } \\
\text { Hewitt tet lal[26] }\end{array}$ & 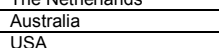 & $\frac{1995}{1995}$ & $\frac{65}{455}$ & 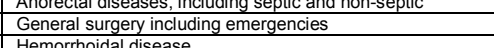 & $\begin{array}{l}\text { AIDS patients with a lower CD4 cells count have a disturbed wound healing } \\
\text { ADS patients have a higher morbidity }\end{array}$ \\
\hline & South Africa & 1997 & 402 & Surgical critical care & $\begin{array}{l}\text { No relevant tifterences in outcomes } \\
\text { HIV positive patients have more often organ faliure and seppic shock- } 54 \% \text { were trauma }\end{array}$ \\
\hline gwanjije et al al.27]] & Australia & 1997 & & ng septic and non-septic & 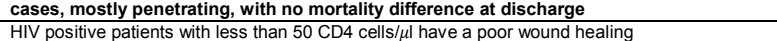 \\
\hline Davis etalt & USA & 1999 & 104 & Vascular & 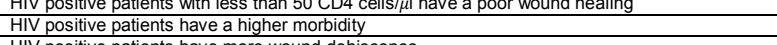 \\
\hline Davis et al.I. & & & 648 & \begin{tabular}{|l|} 
General surgery laparotomy only including $5 \%$ trauma \\
Hemornidisa diseas
\end{tabular} & $\begin{array}{l}\text { HIV positive patients have more wound deniscence } \\
\text { HII positive and AIDS patients have a slower wound healing, AlDS patient have a higher }\end{array}$ \\
\hline (lat & Brazil & 1999 & $\frac{48}{1860}$ & \begin{tabular}{|l|l} 
Hemorrhiodal disease \\
Anorecta diseases including septic and non-septic
\end{tabular} & $\begin{array}{l}\text { morbidity } \\
\text { ADS patients have a slower wound healing }\end{array}$ \\
\hline (lic & & & & \begin{tabular}{|l|} 
Anterectal olseases, incluaing sepicic and non-sepicic \\
All surgical disciplines
\end{tabular} & \\
\hline & USA & & 443 & Critical care & 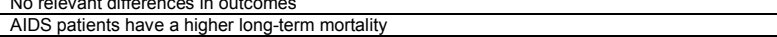 \\
\hline ko and Moc & $\frac{\text { South Africa }}{\text { Malawi }}$ & 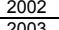 & $\frac{270}{445}$ & issions with <14\%, trauma & HIV positive patients have a higher wound sepsis rate \\
\hline Mkony et al. & Tanzania & 2003 & 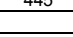 & General surgical patients & $\begin{array}{l}\text { HIV positive patanents have a higher rortality } \\
\text { HIV positive patients have a higher mortality }\end{array}$ \\
\hline & Europe & 2004 & & Matermal mortality and complications in obstetrics & $\begin{array}{l}\text { NN relevant differences in outcomes } \\
\text { HIV Dositive patients have a higher morbidity }\end{array}$ \\
\hline alatal. & $\begin{array}{l}\text { Europe } \\
\text { South Africa } \\
\end{array}$ & $\frac{2004}{2006}$ & 年 500 & 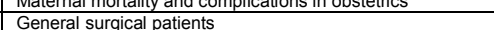 & $\begin{array}{l}\text { HIV positive patainsth have a higher morbiditity } \\
\text { No relevant differences in outcomes }\end{array}$ \\
\hline 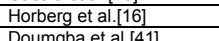 & USA & $\frac{2006}{2006}$ & $\frac{704}{207}$ & $\begin{array}{l}\text { General surgical patients } \\
\text { General surgery elective and emergency cases }\end{array}$ & $\begin{array}{l}\text { No relevant differenceses in outcomes except a higher pneumonia rate } \\
\text { HII positive patients have a higher wound sespis rate }\end{array}$ \\
\hline & South Africa & & 537 & 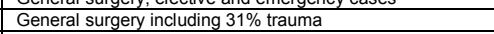 & 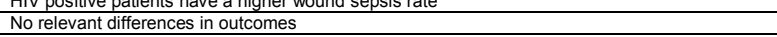 \\
\hline 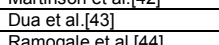 & UK & $\frac{2007}{2007}$ & 477 & 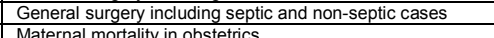 & AIDS patients have a higher morbidity \\
\hline $\begin{array}{l}\frac{R \text { Ramogala et all. } 444]}{\text { Masoomi et al.[45] }} \\
\end{array}$ & & 2011 & 800 & 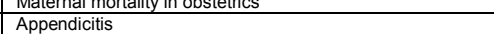 & $\begin{array}{l}\text { HII posisive eatients have a higher rortt } \\
\text { AIDS patients have a higher morbidity }\end{array}$ \\
\hline in etal al 466 & UK & & 44 & Anal cancer & $\begin{array}{l}\text { HIV positive patients have a higher morbidity } \\
\text { Hell }\end{array}$ \\
\hline mehr et al. $[$. & 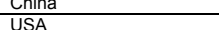 & $\frac{2015}{2016}$ & $\begin{array}{l}\frac{803}{13} \\
3\end{array}$ & 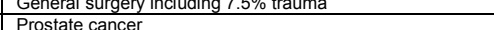 & $\begin{array}{l}\text { Low CD4 count is a risk factor for sepsi } \\
\text { No relevanand differenceses in outcomes }\end{array}$ \\
\hline 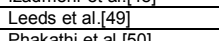 & & & & Anal cancer & $\begin{array}{l}\frac{N}{\text { No relevantint difterences in outcomes }} \\
\text { No relevant differences in outcomes }\end{array}$ \\
\hline Phakathie & South Africa & 2016 & 31 & Breast cancer & No relevant diff \\
\hline 51] & South Africa & 2017 & 675 & Surgical septic patients & $\begin{array}{l}\text { No relevant } \\
\text { mortality }\end{array}$ \\
\hline Irauma & USA & 1996 & 53 & Trauma, blunt and penetrating (57\%) & No relever \\
\hline & USA & 2005 & 1173 & Trauma, predominantly blunt, penetrating (19\%) & Significant pulmonary and infective complications in HIV positive patients, no difference in \\
\hline & & 2008 & & Traum & Significant pulmonary and renal com \\
\hline Mad & Tanzania & 2010 & 250 & & HIV positive patients have a higher $\mathrm{n}$ \\
\hline Ison & USA & 2011 & 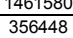 & $\begin{array}{l}\text { Trauma, ppedominantly blunt, penentrating }(11 \%) \\
\text { Trauma, predominantly blunt, penetrating }(<17 \%)\end{array}$ & $\begin{array}{l}\text { Signififant pulmonary commilications i H HII positiviv pataints } \\
\text { HIV was a significant risk factor for complications but not to }\end{array}$ \\
\hline hiet & Iran & 2017 & & Burns only & ger in the ho \\
\hline
\end{tabular}


1. AVERT (2017) History of HIV and AIDS Overview. Retrieved from https://www.avert.org/professionals/history-hiv-aids/overview. Accessed 07/10/2017.

2. SA S (2017) Statistical release - Mid-year population estimates. Retrieved from https://www.statssa.gov.za/publications/P0302/P03022016.pdf. Accessed 07/10/2017.

3. Groenewald P BM, Bradshaw D, Coetzee D, Cornelius K, Daniels J, Evans J, Jacobs, C NI, Msemburi W, Matzopoulos R, Naledi T, Shand L, Thompson V, Vismer M (2017) Western Cape Mortality Profile 2010. Retrieved from http://www.mrc.ac.za/bod/WC2010Report.pdf. Accessed 07/20/2017.

4. Stawicki SP, Hoff $\bar{W}$, Hoey BA, et al (2005) Human immunodeficiency virus infection in trauma patients: where do we stand? J Trauma 58: 88-93

5. Duane TM, Sekel S, Wolfe LG, et al (2008) Does HIV infection influence outcomes after trauma? J Trauma 65: 63-65

6. Morrison CA, Wyatt MM, Carrick MM (2010) Effects of human immunodeficiency virus status on trauma outcomes: a review of the national trauma database. Surg Infect (Larchmt) 11: 41-47

7. Patel MS, Malinoski DJ, Nguyen XM, et al (2011) The impact of select chronic diseases on outcomes after trauma: a study from the National Trauma Data Bank. J Am Coll Surg 212: $96-104$

8. Charlson ME, Pompei P, Ales KL, et al (1987) A new method of classifying prognostic comorbidity in longitudinal studies: development and validation. J Chronic Dis 40: 373-383

9. Champion HR, Sacco WJ, Copes WS, et al (1989) A revision of the Trauma Score. J Trauma 29: 623-629

10. Kobusingye OC, Lett RR (2000) Hospital-based trauma registries in Uganda. J Trauma 48: 498-502

11. AAST (2017) Injury Scoring Scale. Retrieved from http://www.aast.org/library/traumatools/injuryscoringscales.aspx. Accessed $0 \overline{7} \overline{10} / 20 \overline{1} \overline{7}$.

12. Moore EE, Dunn EL, Moore JB, et al (1981) Penetrating abdominal trauma index. J Trauma 21: 439-445

13. Dindo D, Demartines N, Clavien PA (2004) Classification of surgical complications: a new proposal with evaluation in a cohort of 6336 patients and results of a survey. Ann Surg 240: 205-213

14. WHO (2017) WHO - HIV. Retrieved from http://www.who.int/hiv/en/. Accessed $07 / 10 / 2017$.

15. SAHO (2017) South African History Online. Retrieved from http://www.sahistory.org.za/article/hivaids-south-africa-timeline-1940s-2009. Accessed 07/10/2017.

16. Horberg MA, Hurley LB, Klein DB, et al (2006) Surgical outcomes in human immunodeficiency virus-infected patients in the era of highly active antiretroviral therapy. Arch Surg 141: 1238-1245

17. Madiba TE, Muckart DJ, Thomson SR (2009) Human immunodeficiency disease: how should it affect surgical decision making? World J Surg 33: 899-909

18. Hardcastle TC, Hansoti B (2016) HIV, trauma and the emergency departments: The CDC opt-out approach should be adopted in South Africa. S Afr J Bioeth Law 9: 57-60

19. Wakeman R, Johnson CD, Wastell C (1990) Surgical procedures in patients at risk of human immunodeficiency virus infection. J R Soc Med 83: 315-318
Field Code Changed

Field Code Changed

Field Code Changed

Field Code Changed

Field Code Changed

Field Code Changed 
20. Safavi A, Gottesman L, Dailey TH (1991) Anorectal surgery in the HIV+ patient: update. Dis Colon Rectum 34: 299-304

21. Ayers J, Howton MJ, Layon AJ (1993) Postoperative complications in patients with human immunodeficiency virus disease. Clinical data and a literature review. Chest 103: $1800-1807$

22. Binderow SR, Cavallo RJ, Freed J (1993) Laboratory parameters as predictors of operative outcome after major abdominal surgery in AIDS- and HIV-infected patients. Am Surg 59: 754-757

23. Devito JR, Robinson WR (1995) Gynecological surgical outcomes among asymptomatic human immunodeficiency virus-infected women and uninfected control subjects. J La State Med Soc 147: 109-112

24. Consten EC, Slors FJ, Noten HJ, et al (1995) Anorectal surgery in human immunodeficiency virus-infected patients. Clinical outcome in relation to immune status. Dis Colon Rectum 38: 1169-1175

25. Yii MK, Saunder A, Scott DF (1995) Abdominal surgery in HIV/AIDS patients: indications, operative management, pathology and outcome. Aust N Z J Surg 65: 320326

26. Hewitt WR, Sokol TP, Fleshner PR (1996) Should HIV status alter indications for hemorrhoidectomy? Dis Colon Rectum 39: 615-618

27. Bhagwanjee S, Muckart DJ, Jeena PM, et al (1997) Does HIV status influence the outcome of patients admitted to a surgical intensive care unit? A prospective double blind study. BMJ 314: 1077-1081; discussion 1081-1074

28. Lord RV (1997) Anorectal surgery in patients infected with human immunodeficiency virus: factors associated with delayed wound healing. Ann Surg 226: $92-99$

29. Curi MA, Pappas PJ, Silva MB, Jr., et al (1999) Hemodialysis access: influence of the human immunodeficiency virus on patency and infection rates. J Vasc Surg 29: 608616

30. Davis PA, Corless DJ, Gazzard BG, et al (1999) Increased risk of wound complications and poor healing following laparotomy in HIV-seropositive and AIDS patients. Dig Surg 16: 60-67

31. Morandi E, Merlini D, Salvaggio A, et al (1999) Prospective study of healing time after hemorrhoidectomy: influence of HIV infection, acquired immunodeficiency syndrome, and anal wound infection. Dis Colon Rectum 42: 1140-1144

32. Nadal SR, Manzione CR, Galvao VM, et al (1999) Perianal diseases in HIV-positive patients compared with a seronegative population. Dis Colon Rectum 42: 649-654

33. Tran HS, Moncure M, Tarnoff M, et al (2000) Predictors of operative outcome in patients with human immunodeficiency virus infection and acquired immunodeficiency syndrome. Am J Surg 180: 228-233

34. Nickas G, Wachter RM (2000) Outcomes of intensive care for patients with human immunodeficiency virus infection. Arch Intern Med 160: 541-547

35. Jjuuko G, Moodley J (2002) Abdominal wound sepsis associated with gynaecological surgery at King Edward VIII Hospital, Durban. S Afr J Surg 40: 11-14

36. Lewis DK, Callaghan M, Phiri K, et al (2003) Prevalence and indicators of HIV and AIDS among adults admitted to medical and surgical wards in Blantyre, Malawi. Trans R Soc Trop Med Hyg 97: 91-96

37. Mkony C, Kwesigabo G, Lyamuya E, et al (2003) Prevalence and clinical presentation of HIV infection among newly hospitalised surgical patients at Muhimbili National Hospital, Dar es Salaam, Tanzania. East Afr Med J 80: 640-645

38. Narasimhan M, Posner AJ, DePalo VA, et al (2004) Intensive care in patients with HIV infection in the era of highly active antiretroviral therapy. Chest 125: 1800-1804 
39. Fiore S, Newell ML, Thorne C, et al (2004) Higher rates of post-partum complications in HIV-infected than in uninfected women irrespective of mode of delivery. AIDS 18: 933-938

40. Cacala SR, Mafana E, Thomson SR, et al (2006) Prevalence of HIV status and CD4 counts in a surgical cohort: their relationship to clinical outcome. Ann R Coll Surg Engl 88: 46-51

41. Doumgba AD, Kamoune JN, Ngarhio L, et al (2006) [Surgery and HIV in Bangui (Central African Republic)]. Sante 16: 173-176

42. Martinson NA, Omar T, Gray GE, et al (2007) High rates of HIV in surgical patients in Soweto, South Africa: impact on resource utilisation and recommendations for HIV testing. Trans R Soc Trop Med Hyg 101: 176-182

43. Dua RS, Wajed SA, Winslet MC (2007) Impact of HIV and AIDS on surgical practice. Ann R Coll Surg Engl 89: 354-358

44. Ramogale MR, Moodley J, Sebiloane MH (2007) HIV-associated maternal mortality-primary causes of death at King Edward VIII Hospital, Durban. S Afr Med J 97: $363-$ 366

45. Masoomi H, Mills SD, Dolich MO, et al (2011) Outcomes of laparoscopic and open appendectomy for acute appendicitis in patients with acquired immunodeficiency syndrome. Am Surg 77: 1372-1376

46. Cunin L, Alfa-Wali M, Turner J, et al (2014) Salvage surgery for residual primary and locally recurrent anal squamous cell carcinoma after chemoradiotherapy in HIVpositive individuals. Ann Surg Oncol 21: 527-532

47. Feng T, Feng X, Jiang C, et al (2015) Sepsis risk factors associated with HIV-1 patients undergoing surgery. Emerg Microbes Infect 4: e59

48. Izadmehr S, Leapman M, Hobbs AR, et al (2016) Clinical characteristics and outcomes of HIV-seropositive men treated with surgery for prostate cancer. Int Urol Nephrol 48: 1639-1645

49. Leeds IL, Alturki H, Canner JK, et al (2016) Outcomes of abdominoperineal resection for management of anal cancer in HIV-positive patients: a national case review. World J Surg Oncol 14: 208

50. Phakathi BP, Basson G, Karusseit VO, et al (2016) The effect of HIV infection on the surgical, chemo- and radiotherapy management of breast cancer. A prospective cohort study. Int J Surg 34: 109-115

51. Green S, Kong VY, Odendaal J, et al (2017) The effect of HIV status on clinical outcomes of surgical sepsis in KwaZulu-Natal Province, South Africa. South African medical journal = Suid-Afrikaanse tydskrif vir geneeskunde 107: 702-705

52. Guth AA, Hofstetter SR, Pachter HL (1996) Human immunodeficiency virus and the trauma patient: factors influencing postoperative infectious complications. J Trauma 41: 251-255; discussion 255-256

53. Mayala V, Mshana SE, Chalya PL, et al (2010) Prevalence of HIV infection among trauma patients admitted to Bugando Medical Centre, Mwanza, Tanzania and its influence on outcome. Tanzan J Health Res 12: 222-228

54. Salehi SH, As'adi K, Tabatabaeenezhad SA, et al (2017) Prevalence of HIV infection among burn patients: is there a relationship with patients' outcomes? Int Wound J 14: $85-88$ 